\title{
ÓPẼ E A TERRA INDÍGENA DE IRAÍ: CONQUISTA, DESAFIOS E PERSPECTIVAS
}

VALDEMAR VICENTE ${ }^{1}$

Bom, fazendo um breve histórico, né, quanto à nossa aldeia lá na beira do Rio do Mel. Na época, eu apenas tinha 16 anos, né e já lá com o decorrer do tempo o Augusto já era um homem já reconhecido a nível de Brasília, né, naquela época. Então, me lembro que a primeira viagem que a gente fez pra lá era com ele que eu fiz e eu acho que, durante esse período, o Augusto lutou pelo bem estar da comunidade, né? Porque lá embaixo a gente sofria as consequências das cheias, né? Então, volta e meia a gente sofria bastante. E agora, com a mudança para cá, a gente... É claro que não tinha estrutura nenhuma aqui em cima. As famílias que não eram índio moravam aqui, as casinhas eram muito... Muito... Já digo, assim, de resto de material. Eu acho que a luta do Augusto, ele abriu novos horizontes, novos caminhos para o povo Kaingang, na época. Com a conquista da Terra Indígena de Iraí, ela abriu a visão de outras Lideranças, abriu a força, a coragem de outras lideranças. Eu me lembro quando a terra estava com a demarcação já, com a portaria pra demarcar a área e a Funai [Fundação Nacional do Índio] também não queria demarcar, né? E, daí, houve a pressão da prefeitura na época, e aí que fizemos a autodemarcação. Fizemos a demarcação simbólica e com todos os grupos de outras aldeias, no caso de Votoro, o pessoal de Rio da Várzea... Então, eu acho que a nossa Liderança, ela lutou por só um objetivo. O Augusto mudava as suas Lideranças, mas era um único objetivo era de conquistar esse espaço. Então, pra nós é uma luta, uma conquista, para nós, fomos vitoriosos naquela época. $E$, agora, existe as novas estruturas em cima, né, a gente está vendo que evoluiu bastante com a conquista que o seu Augusto e a

\footnotetext{
${ }^{1}$ Agente de Saúde Indígena da comunidade de Iraí. Liderança da Comunidade Indígena Kaingang de Iraí.
} 
sua própria comunidade, naquela época, que era bem pouco, mesmo. Mas a gente pretende também pedir aos nossos companheiros kaingang, outros caciques, de cada vez mais se unir, né, diante da perda desse grande líder que era reconhecido a nível nacional, a nível de outros países da América, né? E ele foi muito reconhecido, líder muito, assim, de defender os direitos indígenas. Embora que ele tinha pouco conhecimento das leis, mas tudo que ele falava era baseado na Constituição. Então, parecia, quem enxergava ele era um homem que tinha faculdade. Isso, eu hoje penso como, aonde ele buscou esse conhecimento. Então, hoje, a nossa preocupação muito hoje de tudo que ele tinha esse conhecimento, é de nós passar para os nossos filhos como defender o seu povo. Porque a gente sabe que é difícil de coordenar um povo. Como ele sempre fala nas suas falas de reuniões, assim, na comunidade ele sempre fala que não é fácil coordenar um grupo, uma comunidade, né? Tem que ter planejamento - esse era um versão que ele sempre falava. E, na verdade, ele era certo. Então, através de planejamentos e pensamentos em conjunto que se consegue as coisas. Sozinho ninguém consegue. $\mathrm{E}$ a gente lamenta muito com a perda do tio Augusto, me criei com ele e hoje, até hoje eu falo pra juventude hoje, porque o grande objetivo dele é de formar jovens líderes aqui na comunidade. Então, a gente está trabalhando em cima, junto com as Lideranças, para também que aconteça essa formação de jovens Lideranças, porque um dia eles vão ter que botar o seu rosto à frente da comunidade, pra defender seu povo. Porque nós já estamos indo, estamos velhos, já. E a gente pede, né, a todas as Lideranças do Rio Grande do Sul, se una cada vez mais pra gente ao menos conquistar os nossos territórios que ainda falta regularizar, né? E tanto é que aqui é uma aldeia, uma Terra Indígena muito pequena. O que nós ocupemos é uma média de 120 hectares de terra devastada, né? E maior parte é mato nativo que é intocável, né? Então, isso, a gente pensa hoje, o que será daqui 20 anos dessa nova geração que está surgindo. E isso nós estamos já conversando, entre nós. Porque a gente já tem que olhar lá pra frente, porque daqui 20,30 anos não vai ter mais espaço aqui em cima. Então, são essas... O que a gente vem pensando e a preocupação nossa é muito grande nessa parte. Tanto é que as políticas públicas, hoje, ela não fala da situação dos indígenas hoje, né? Tem uns $10 \ldots 8$, 
10 anos pra cá já esqueceram dos índios, né? Então, a gente pede apoio de outras lideranças pra se encaixar junto nessa luta, né? Porque o único bem que nós temos que deixar para os nossos filhos é terra. Porque deixar eles em liberdade, uma terra conquistada, uma terra regularizada, uma terra ampliada... Isso que a gente queria. Mas com esse processo da política do governo federal, ela parou tudo, né? Isso, a gente lamenta muito, né, e por isso que a gente quer que... A gente sente muito a perda do tio Augusto. E ele é um desses que sempre mexe lá em Brasília, mexe no estado, mexe lá fora, fora do Brasil. Então, são as coisas que a gente sente muito por isso. Então, mediante as entidades, as ONGs [Organizações Não Governamentais] de apoio, tinha que ter preocupação com essa Terra Indígena, que é muito pequena. Hoje, nós deve ter... Nós estamos fazendo o novo censo agora e, a partir do ano que vem, a gente vai ter mais que 150 famílias. Então, são essas coisas que a gente se preocupa. E tanto é que o tio Augusto também se preocupava muito. Então, tudo que ele deixou planejado é um dos nossos objetivos pra ampliar a terra, né, dos nossos filhos. E sei que com saudade temos, mas... O tempo é assim, né? O tempo, ela chega pra cada um, a hora, né? Então, chegou a hora do tio Augusto, ele já foi descansar e nós temos que trabalhar, né, pra defender nosso povo, pra buscar melhorias pra nossa comunidade. Então, tudo isso pra nós é saudade, mas ele deixou a nossa comunidade em liberdade. Hoje, temos aqui... Hoje, não estamos acampados mais. Antigamente, a prefeitura do Município de Iraí sempre queria carregar nós pra outro lugar. Tanto é que pela resistência daquelas famílias que hoje estão aqui, já são de certas idades, né? Então, a gente permaneceu e hoje conquistamos esse espaço. Então, para nós foi muito válido o passo que o seu Augusto, o tio Augusto tinha dado, né? Não foi em vão o passo, naquela época nós era bem-organizado. E pretendemos cada vez mais se organizar e somar força pra nós alcançar nossos objetivos, o plano que o tio Augusto tinha com essa comunidade. Então, são essas palavras que eu tenho a falar a todo o Rio Grande do Sul. 